\title{
Does leukocyte-poor or leukocyte-rich platelet-rich plasma applied with biopolymers have superiority to conventional platelet-rich plasma applications on chondrocyte proliferation?
}

\author{
Biyopolimerler ile uygulanan lökositten fakir veya lökositten zengin trombositten \\ zengin plazmanın kondrosit proliferasyonunda konvansiyonel trombositten \\ zengin plazma uygulamalarına üstünlüğü var mıdır?
}

\author{
Duygu Yaşar Şirin, PhD., İbrahim Yılmaz, MD., ${ }^{2}$ Mehmet İsyar, MD., ${ }^{3}$ \\ Kadir Öznam, MD., ${ }^{4}$ Mahir Mahiroğulları,MD. ${ }^{5}$ \\ 'Department of Biology, Namık Kemal University, Faculty of Arts and Science, Tekirdağ, Turkey \\ ${ }^{2}$ Department of Medical Pharmacology, İstanbul Medipol University School of Medicine, İstanbul, Turkey \\ ${ }^{3}$ Department of Orthopaedic and Traumatology, Acıbadem Hospitals Group, İstanbul, Turkey \\ ${ }^{4}$ Department of Orthopaedic and Traumatology, İstanbul Medipol University School of Medicine, İstanbul, Turkey \\ ${ }^{5}$ Department of Orthopaedic and Traumatology, Memorial Health Group, İstanbul, Turkey
}

\begin{abstract}
Objectives: This study aims to investigate the possible effects of leukocyte concentration in the content of platelet-rich plasma (PRP) and the administration of PRP using a drug delivery system on chondrocyte proliferation in vitro conditions.

Patients and methods: Blood from nine male patients (mean age 65 years; range 49 to 81 years) with advanced stage osteoarthritis who had not responded to medical or conservative treatments and underwent total knee arthroplasty was used to prepare two formulations: PRP with low concentration leukocytes (2000-4000 leukocytes/ $\mu \mathrm{L})$ was designated as pure PRP (P-PRP), whereas PRP with high concentration leukocytes (9000-11000 leukocytes/ $\mu \mathrm{L})$ as leukocyte-rich PRP (L-PRP). Samples were divided into five groups as control group (group 1), chondrocyte cultures with P-PRP applied directly (group 2), chondrocyte cultures with L-PRP applied directly (group 3), chondrocytes co-cultured with P-PRP applied hydrogel (group 4), and chondrocytes co-cultured with L-PRP applied hydrogel (group 5). In all groups; cell morphology, viability and proliferation were compared with the expression of stagespecific embryonic antigen-1 (SSEA-1), a precondrocyte marker.
\end{abstract}

Results: Maximum cell proliferation and SSEA-1 expression occurred in group 4, with a statistically significant correlation between SSEA-1 expression and cell proliferation.

Conclusion: Our study showed the importance of leukocyte concentration of PRP and efficiency of delivery systems such as hydrogel and that L-PRP administered with a delivery system is more efficient than conventional applications of PRP in the treatment of cartilage damage.

Keywords: Co-culture techniques; hydrogel; platelet-rich plasma; stage-specific embryonic antigens.
ÖZ

Amaç: Bu çalışmada trombositten zengin plazma (TZP) içeriğindeki lökosit konsantrasyonunun ve TZP'nin ilaç taşıyıcı sistem kullanılarak uygulanmasının in vitro koşullarda kondrosit proliferasyonu üzerine olası etkileri araştırıldı.

Hastalar ve yöntemler: Medikal veya konservatif tedaviye yanıt vermemiş ve total diz artroplastisi geçirmiş dokuz erkek hastanın (ort. yaş 65 yıl; dağılım 49-81 yıl) kanı iki formülasyon hazırlamak üzere kullanıldı: Düşük konsantrasyon lökositli TZP (2000-4000 lökosit/ $\mu \mathrm{L}$ ) saf TZP (S-TZP) olarak, yüksek konsantrasyon lökositli TZP (9000-11000 lökosit/ $\mu \mathrm{L}$ ) ise lökositten zengin TZP (L-TZP) olarak belirlendi. Numuneler kontrol grubu (grup 1), direkt S-TZP uygulanan kondrosit kültürleri (grup 2), direkt L-TZP uygulanan kondrosit kültürleri (grup 3), S-TZP uygulanan hidrojel ile kültürlenen kondrositler (grup 4) ve L-TZP uygulanan hidrojel ile kültürlenen kondrositler (grup 5) olmak üzere beş gruba ayrıldı. Tüm gruplarda hücre morfolojisi, canlılık ve proliferasyon bir prekondrosit belirteci olan evreye özgü embriyonik antijen 1'in (SSEA-1) ifadesi ile karşılaştırıldı.

Bulgular: Maksimum hücre proliferasyonu ve SSEA-1 ifadesi grup 4'te gerçeklești; SSEA-1 ifadesi ve hücre proliferasyonu arasında istatistiksel olarak anlamlı ilişki vardı.

Sonuç: Çalışmamız TZP'nin lökosit konsantrasyonunun ve hidrojel gibi taşıyıcı sistemlerin önemini ve taşıyıcı sistem ile uygulanan L-TZP'nin kıkırdak hasarının tedavisinde TZP'nin konvansiyonel uygulamalarından daha etkin olduğunu gösterdi.

Anahtar sözcükler: Eşkültür teknikleri; hidrojel; trombositten zengin plazma; evreye özgü embriyonik antijenler.

- Received: February 10, 2017 Accepted: July 25, 2017

- Correspondence: Duygu Yaşar Şirin, PhD. Namık Kemal Üniversitesi, Fen Edebiyat Fakültesi, Biyoloji Bölümü, 59030 Tekirdağ, Turkey. Tel: +90 505 - 6507636 e-mail: dysirin@nku.edu.tr 
Osteoarthritis (OA), a degenerative joint disease, is a major cause of physical disability which results in impaired quality of life and which cannot be remediated spontaneously. Unfortunately, current pharmacological and surgical treatment approaches are still not sufficient to achieve a complete treatment. ${ }^{[1]}$

Platelet-rich plasma (PRP), which has important functions in blood coagulation and homeostasis, is used as a non-pharmaceutical agent supporting the normal healing process by releasing growth factors to the local environment for the treatment of cartilage damage or OA occurred after damage. ${ }^{[2]}$ Platelet-rich plasma has been reported as effective in treatment and holds great promise in almost all fields of medicine. ${ }^{[3]}$ However, PRP has been prepared with different contents and concentrations or by means of different ready-to-use commercial kits, leading to a questionable success of PRP therapy. ${ }^{[4,5]}$ After all, it appears from the current literature that more in-depth studies are needed to reveal the effects of PRP containing different concentrations of platelets and also leukocytes, particularly on chondrocytes and chondrocyte proliferation. ${ }^{[5]}$

Additionally, there are at least two more important issues that have not been fully elucidated in the PRP-related literature. The first is peptide growth factors in PRP, which have short half-life of two minutes at most, in that therapeutic efficiency of these growth factors is still a question unless they are delivered with a drug carrier matrix. ${ }^{[6]}$ A drug carrier system such as biocompatible hydrogels has great capacity to maintain and prolong the halflife of peptide growth factors in PRP. Secondly, the expression of stage-specific embryonic antigen-1 (SSEA-1), a prechondrocyte differentiation marker, has not been investigated in chondrocyte cell cultures subjected to PRP. SSEA-1 expression may indicate maturated chondrocyte proliferation, which is a desired marker for proper treatment of cartilage.

In this respect, the following questions are required to be answered: (i) Can we increase the bioactivity of PRP using a drug delivery system? (ii) Does leukocyte concentration of PRP have any effect on chondrocyte proliferation? (iii) If PRP has such an effect, then what should be the appropriate leukocyte concentration of PRP? (iv) Does PRP administration support extracellular matrix formation in the tissue? Therefore, in this study, we aimed to investigate the possible effects of leukocyte concentration in the content of PRP and the administration of PRP using a drug delivery system on chondrocyte proliferation in vitro conditions.

\section{PATIENTS AND METHODS}

This study was conducted at Medipol Istanbul University, Faculty of Medicine between January 2015 and August 2016. Blood from nine male patients (mean age 65 years; range 49 to 81 years) with advanced stage osteoarthritis who had not responded to medical or conservative treatments and underwent total knee arthroplasty was used to prepare two formulations: PRP with low concentration leukocytes (2000-4000 leukocytes $/ \mu \mathrm{L}$ ) was designated as pure PRP (P-PRP), whereas PRP with high concentration leukocytes (9000-11000 leukocytes/ $\mu \mathrm{L})$ as leukocyte-rich PRP (L-PRP). Samples were divided into five groups as control group (group 1), chondrocyte cultures with P-PRP applied directly (group 2), chondrocyte cultures with L-PRP applied directly (group 3), chondrocytes co-cultured with P-PRP applied hydrogel (group 4), and chondrocytes co-cultured with L-PRP applied hydrogel (group 5). The experimental design of groups was given in Table I. The study protocol was approved by the Medipol Istanbul University, Faculty of Medicine Ethics Committee (10840098-296/24.11.2014). A written informed consent was obtained from each patient. The study was conducted in accordance with the principles of the Declaration of Helsinki.

To minimize experimental inaccuracies, similar analyses were performed by the same researcher and a blinding method was applied in the preparation of hydrogel and PRP, which were prepared in a closed system under aseptic conditions to avoid contamination. The experiments were repeated six times for each experimental group.

Cell viability, toxicity and proliferation in all experimental and control groups were determined by MTT (3-[4,5-dimethylthiazol-2-yl]-2,5diphenyltetrazolium bromide; Thiazolyl blue) analysis after 24 hours and on days 10 and 21, and SSEA-1 expression with commercial enzyme-linked immunosorbent assay (ELISA) kit. Simultaneously, environmental scanning electron microscope (ESEM) and inverted light microscope images were recorded.

Patients had stage 4 gonarthrosis according to Kellgren-Lawrence scale. ${ }^{[7]}$ The hematocrit levels were 42\%-52\%. In order to prepare the PRP, patients were invited to the clinic on the $21^{\text {st }}$ day after surgery for autologous blood collection.

Patients who used non-steroid anti-inflammatory, anti-thrombotic or anti-coagulant drugs in the last two weeks or consumed alcohol and/or cigarettes in the last 48 hours were excluded. Also, complete blood count and electrocardiogram test results were evaluated and patients with arrhythmia, anemia, 
TABLE I

Experimental design of groups

\begin{tabular}{llc}
\hline Group & Description & Application \\
\hline Group 1 & Control & $(-)$ \\
Group 2 & Monolayer chondrocyte culture & P-PRP \\
Group 3 & Monolayer chondrocyte culture & L-PRP \\
Group 4 & Hydrogel and chondrocyte co-culture & P-PRP \\
Group 5 & Hydrogel and chondrocyte co-culture & L-PRP \\
\hline P-PRP: Pure platelet-rich plasma; L-PRP: Leukocyte-platelet-rich plasma.
\end{tabular}

polycythemia, and thrombotic disease were excluded. Finally, standard primary chondrocyte cultures were performed from osteochondral tissues obtained from the remaining nine eligible patients.

Tissues from lateral and medial femoral condyles as well as the tibial plateau are routinely removed during total knee arthroplasty and treated as surgical waste. These osteochondral tissues were retained during surgery and transferred to our cell culture laboratory under sterile conditions. Standard primary culture protocols were followed to obtain a monolayer human primary chondrocyte culture.

Chondrocytes were detached from the culturevessel surfaces using trypsin- ethylenediaminetetraacetic, and then stained with Trypan blue and counted with a Neubauer Chamber. Approximately $3.2 \times 10^{4}$ cells were placed in each well in a 96-well plate for MTT analysis (Vybrant MTT Cell Proliferation assay) (Cat\# V-13154), Cell Biolabs Inc., USA), and $9.5 \times 10^{5}$ cells in each well in six-well plate for hydrogel applications and $8 \times 10^{5}$ cells in $35 \mathrm{~mm}$ petri dishes for ESEM evaluations. All cultures were incubated for 24 hours for cells to attach and proliferate. Cell culture media supplemented with 6.5\% PRP in addition to standard ingredients were refreshed every other day in P-PRP and L-PRP experimental groups.

For photoactivated PRP preparation, autologous blood $(24 \mathrm{~mL})$ was taken from patients and aliquoted into $3 \times 8.5 \mathrm{~mL}$ vacutainer tubes containing trisodium citrate $(22.0 \mathrm{~g} / \mathrm{L})$, citric acid $(8.0 \mathrm{~g} / \mathrm{L})$, and dextrose $(24.5 \mathrm{~g} / \mathrm{L})$ (BD Vacutainer ${ }^{\circledR}$, Becton Drive, Franklin Lakes, NJ, USA). After centrifugation at $1000 \mathrm{rpm}$ for 10 minutes, platelet-poor plasma, buffy coat layer (containing PRP and leukocytes) and a red blood cell layer were separated. Platelet-poor plasma was withdrawn from each tube to the level of $10 \mathrm{~mm}$ above the buffy coat and discarded. The remaining plasma and the buffy coat were withdrawn into a single sterile tube and exposed to photoactivation for 10 minutes $^{[8]}$ which were achieved using the commercial device Adi-Light 2 (AdiStem Ltd., Hong Kong). Total cell count was performed for the same remaining plasma and the buffy coat using a hematology analyzer (Sysmex XT-2000i; Roche Diagnostics, Basel, Switzerland) and white blood cells were counted based on morphological characteristics of the cells after Giemsa staining with light microscope.

Obtained P-PRP and L-PRP were added to the hydrogel at a concentration of $6.5 \%$. Since PRP cryopreservation is a safe procedure, ${ }^{[0]}$ the remaining PRP was stored for use on days 10 and 21.

For the preparation of hydrogel with PRP, 12\% polyvinyl alcohol solution and $4 \%$ starch solution were mixed and stirred until they become homogeneous so that weak cross-links could be formed in this mixture. Autologous PRP obtained from patients under aseptic conditions was added to this mixture at a final concentration of $6.5 \%$ and mixed well with the vortex. Afterwards, a saturated solution of sodium tetraborate $(16 \%)$ was added by mixing. Thus, this biocompatible hydrogel with more stable cross-links was obtained, which behaves like an osmotic pump and maintains the controlled release of PRP. ${ }^{[10]}$ Hydrogel prepared with PRP in this manner is suitable for surgical applications, and at the application area, this hydrogel lasts 21 days with no degradation.

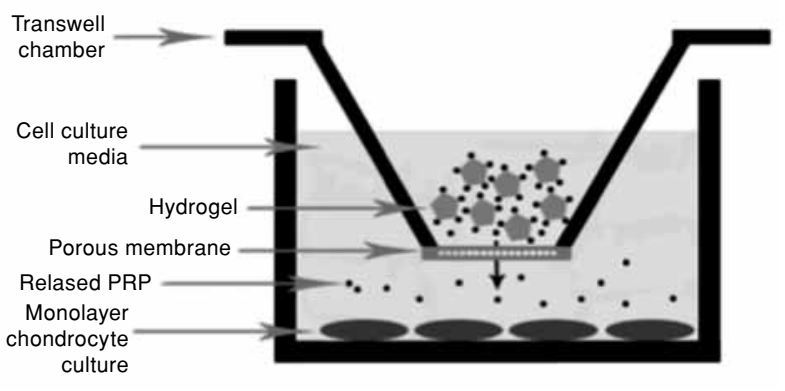

Figure 1. Graphic representation of platelet-rich plasma application with hydrogel delivery system showing controlled released platelet-rich plasma migrating from upper chamber to lower chamber through a porous filter. PRP: Platelet-rich plasma 


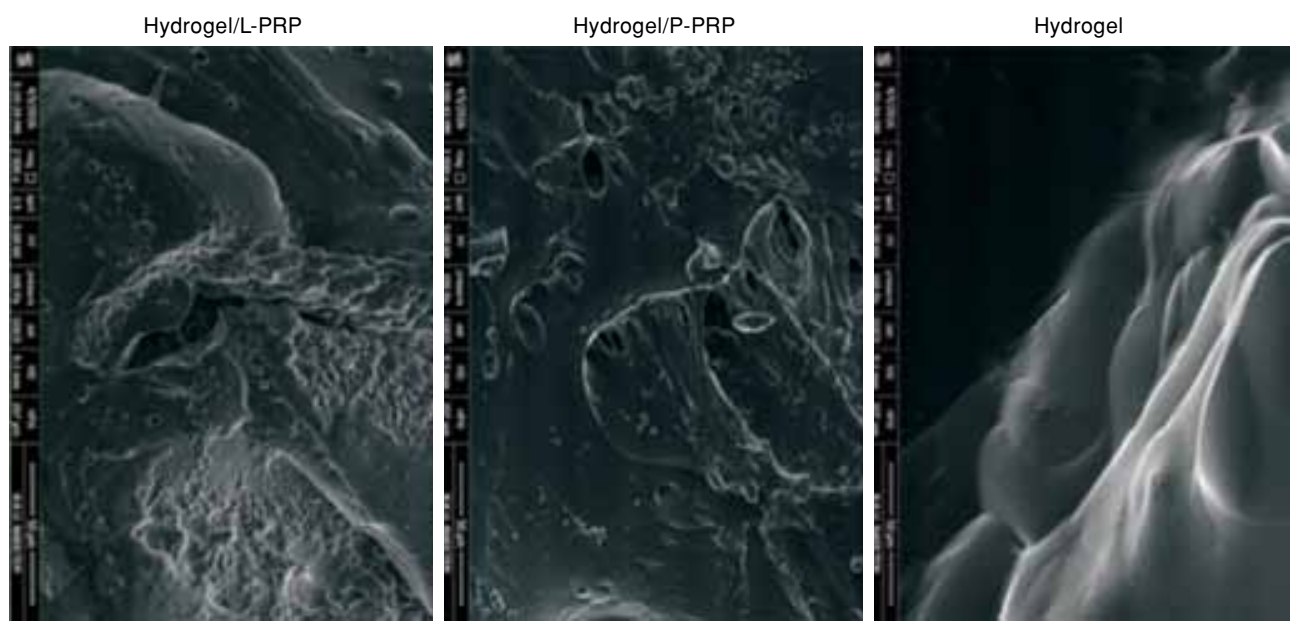

Figure 2. Environmental scanning electron microscope images of hydrogels. P-PRP: Pure platelet-rich plasma; L-PRP: Leukocyte-platelet-rich plasma.

Hydrogels prepared in equal volumes was placed on the upper part of transwell chambers. Schematic representation of the experimental design was given in Figure 1. The chamber was placed on the monolayer chondrocyte culture, and the culture was monitored regularly by changing the nutrient medium every two days.

Cell morphology and confluency were analyzed using an inverted CKX41 Olympus microscope (Olympus Optical Co. Ltd. Hatagaya, Shibuya-ku Japan). Microphotographs of the cell organizations were obtained and analyzed at $4 \times, 10 \times, 20 \times$ and $40 \times$ magnifications in the confocal/contrast phase before and after PRP applications with the Olympus Cell Soft Imaging System software. A Quanta 250 Field emission gun (Fei Company, Hillsboro, Oregon, USA) ESEM was used for electron microscopy. ESEM analysis was carried out to assess the surface topography and composition of the samples. A device with a lifting system and the ability to transfer the electron beam in a high vacuum was used. This enabled us to obtain images of the extracellular matrix, as well as the characteristic cellular structures. ${ }^{[1]}$

Images of hydrogels were taken at a pressure of $100 \mathrm{~Pa}$ in ESEM vacuum mode, under magnification of 2,000x, at a resolution depth (horizontal field width [HFW]) of $207 \mu \mathrm{m}$, at an operating voltage of $5.00 \mathrm{kV}$, and at a wavelength-dispersive (WD) of 9.1-9.5 mm (Figure 2). Images of chondrocytes were taken at a pressure of 220-221 Pa in ESEM vacuum mode, under magnification of 5,000×, at a resolution depth (HFW) of $82.9 \mu \mathrm{m}$, at an operating voltage of $5.00-10.00 \mathrm{kV}$, and at a WD of 8.3-10.7 mm (Figure 3).
The ELISA analyses were performed after 24 hours and on days 10 and 21 using a MR-96A, Mindray microplate reader (Mindray Bio-Medical Electronics Co. Ltd., Shenzhen, PRC) according to the commercial kit manual. For ELISA analysis, $3.2 \times 104$ cells were placed into each well of the black 96-well microplates provided by kit and incubated overnight at $37^{\circ} \mathrm{C}$ in a cell culture incubator. Cells were fixed with $50 \mu \mathrm{L}$ of fixing solution and the assay was performed immediately after cell fixation. Cells were washed

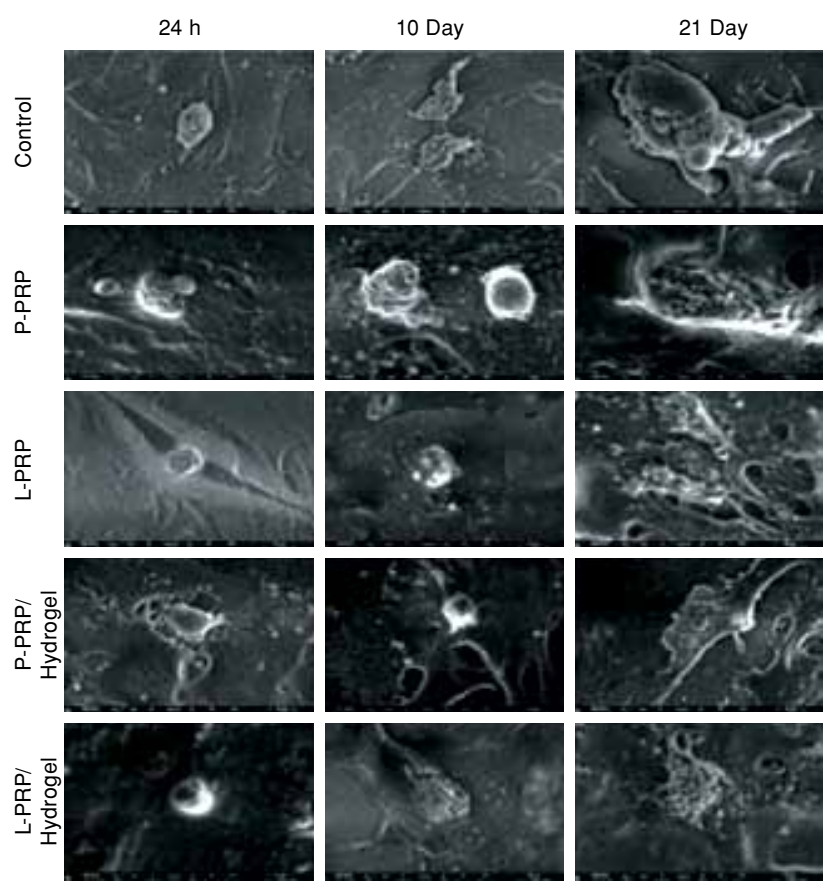

Figure 3. Environmental scanning electron microscope images of chondrocytes. P-PRP: Pure platelet-rich plasma; L-PRP: Leukocyteplatelet-rich plasma. 

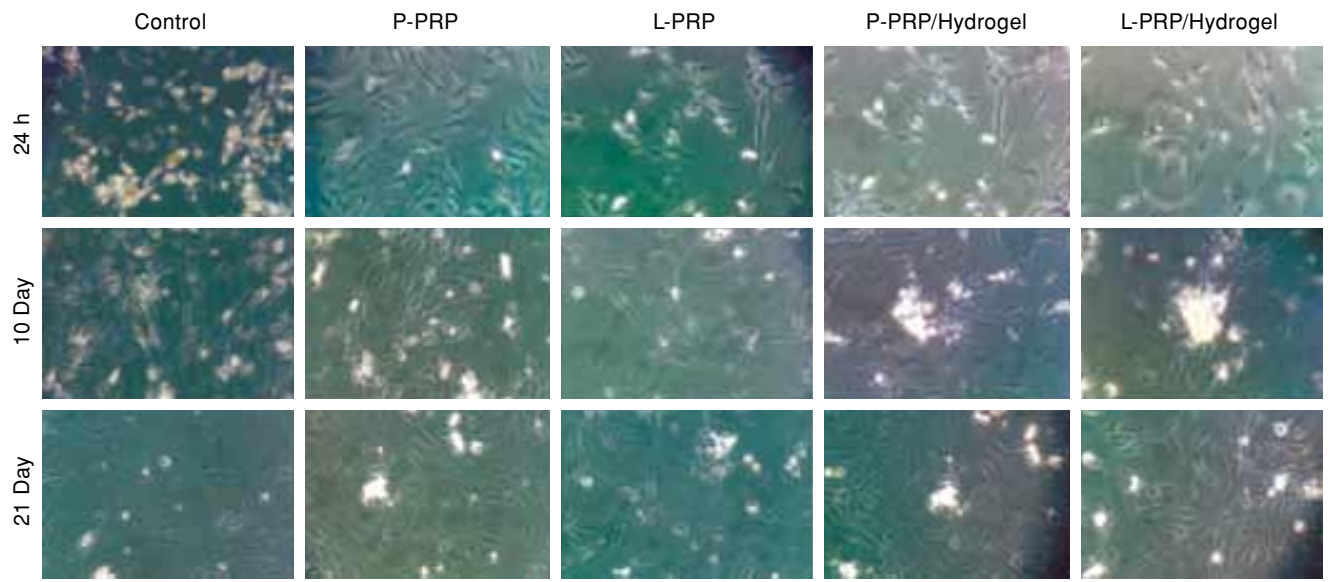

Figure 4. Inverted microscopy of chondrocyte cultures. P-PRP: Pure platelet-rich plasma; L-PRP: Leukocyte-plateletrich plasma.

three times with $50 \mu \mathrm{L}$ of wash buffer for five minutes with gentle shaking. Cell dehydration solution of $50 \mu \mathrm{L}$ was added to each well and incubated. Cells were washed again with wash buffer. After incubating one hour with $50 \mu \mathrm{L}$ of blocking buffer, cells were washed and labeled in order with primary and secondary antibodies for two hours. Substrate MN1 of $50 \mu \mathrm{L}$ was added to each well and incubated for 20 minutes at room temperature. The plates were read using a fluorescence plate reader with excitation at $540 \mathrm{~nm}$ and emission at $600 \mathrm{~nm}$.

Viability tests were carried out by a commercial MTT kit according to the manufacturer's instructions. A 12 mM MTT stock solution was prepared by adding $1 \mathrm{~mL}$ of sterile phosphate buffered saline to a $5 \mathrm{mg}$ vial of MTT. After removing cell culture medium, $90 \mu \mathrm{L}$ of fresh culture medium and $10 \mu \mathrm{L}$ of MTT stock solution were added per well and incubated at $37^{\circ} \mathrm{C}$ for two hours, protected from light. Afterwards, $50 \mu \mathrm{L}$ of dimethyl sulfoxide was added to each well and mixed thoroughly with a pipette, then incubated at $37^{\circ} \mathrm{C}$ for an additional 10 minutes prior to its photometric measurement at a $570 \mathrm{~nm}$ wavelength. The viability of the control group was assumed to be $100 \%$ prior to addition of PRP (at 0 hours) to the culture medium.

Stage-specific embryonic antigen- 1 is up-regulated during the differentiation of human mesenchymal stem cells and controversially downregulated in undifferentiated cells. Therefore, SSEA- 1 expression is considered as a differentiation marker. In drug trials, increased or decreased SSEA-1 in cultured cells is determined without the need to prepare cell lysates. For this purpose, we used a commercial human prechondrocyte characterization kit (Cat\#K36094-21A,

\section{TABLE II}

Comparison of difference between experimental groups: variance analysis of stage-specific embryonic antigen-1, enzyme-linked immunosorbent assay and variance analysis of MTT analyses

\begin{tabular}{|c|c|c|c|c|c|}
\hline \multirow[b]{2}{*}{ Source } & \multicolumn{5}{|c|}{ Variance analysis of SSEA-1 ELISA analysis } \\
\hline & Degree of freedom & Adjusted sum of squares & Adjusted mean squares & F-value & $p$ \\
\hline Method & 14 & 6.51729 & 0.465521 & 22752.72 & 0.000 \\
\hline Error & 75 & 0.00153 & 0.000020 & & \\
\hline \multirow[t]{2}{*}{ Total } & 89 & 6.51882 & & & \\
\hline & \multicolumn{5}{|c|}{ Variance analysis of MTT analysis } \\
\hline Source & Degree of freedom & Adjusted sum of squares & Adjusted mean squares & F-value & $p$ \\
\hline Method & 14 & 14.6339 & 1.04528 & 134971.53 & 0.000 \\
\hline Error & 75 & 0.0006 & 0.00001 & & \\
\hline Total & 89 & 14.6345 & & & \\
\hline
\end{tabular}


Celprogen, USA). ${ }^{[12]}$ Based on the manufacturer's protocol, measurements were carried out using a fluorescence plate reader with excitation at $540 \mathrm{~nm}$ and emission at $600 \mathrm{~nm}$.

\section{Statistical analysis}

Descriptive statistics were expressed as mean \pm standard deviation. Minitab R16 (Minitab Inc., State College, Pennsylvania, USA) program was used for statistical evaluation. Assessments were carried out at $95 \%$ confidence interval. The significance of the difference between groups was evaluated with the analysis of variance.

A posthoc test with multiple pairwise comparisons, namely the Tukey Honestly Significant Difference (HSD) test, was performed in case of difference between groups to determine the group in which

\section{TABLE III}

Comparison of difference between experimental groups: Tukey Pairwise Comparisons for Stage-specific embryonic antigen-1 and MTT analysis

Tukey Pairwise Comparisons for SSEA-1 (Grouping information using the Tukey Method and $95 \%$ confidence interval)

\begin{tabular}{llcc}
\hline Experimental group & $\mathrm{n}$ & Mean* & Grouping $^{\star *}$ \\
\hline Group 4. Day 21 & 6 & 1.06017 & $\mathrm{~A}$ \\
Group 1. Day 21 & 6 & 0.94633 & $\mathrm{~B}$ \\
Group 4. Day 10 & 6 & 0.89600 & $\mathrm{C}$ \\
Group 2. Day 21 & 6 & 0.74317 & $\mathrm{D}$ \\
Group 2. Day 10 & 6 & 0.71883 & $\mathrm{E}$ \\
Group 1. Day 10 & 6 & 0.63533 & $\mathrm{~F}$ \\
Group 5. Day 21 & 6 & 0.54583 & $\mathrm{G}$ \\
Group 1. 24h & 6 & 0.48133 & $\mathrm{H}$ \\
Group 5. Day 10 & 6 & 0.42217 & $\mathrm{I}$ \\
Group 3. 24h & 6 & 0.41367 & $\mathrm{I}$ \\
Group 2. 24h & 6 & 0.38133 & $\mathrm{~J}$ \\
Group 3. Day 21 & 6 & 0.33133 & $\mathrm{~K}$ \\
Group 3. Day 10 & 6 & 0.31250 & $\mathrm{~L}$ \\
Group 5. 24h & 6 & 0.17700 & $\mathrm{M}$ \\
Group 4. 24h & 6 & 0.14417 & $\mathrm{~N}$ \\
\hline
\end{tabular}

Tukey Pairwise Comparisons for MTT-cell viability toxicity and proliferation (Grouping information using the Tukey Method and 95\% confidence interval)

\begin{tabular}{lllc}
\hline Experimental group & $\mathrm{n}$ & Mean & Grouping $^{\star *}$ \\
\hline Group 4. Day 21 & 6 & 1.69133 & $\mathrm{~A}$ \\
Group 4. Day 10 & 6 & 1.25367 & $\mathrm{~B}$ \\
Group 5. Day 10 & 6 & 1.09800 & $\mathrm{C}$ \\
Group 5. Day 21 & 6 & 1.08800 & $\mathrm{D}$ \\
Group 2. Day 21 & 6 & 0.94583 & $\mathrm{E}$ \\
Group 2. Day 10 & 6 & 0.84150 & $\mathrm{~F}$ \\
Group 1. Day 21 & 6 & 0.60700 & $\mathrm{G}$ \\
Group 1. Day 10 & 6 & 0.50100 & $\mathrm{H}$ \\
Group 1. 24h & 6 & 0.47600 & $\mathrm{I}$ \\
Group 3. 24h & 6 & 0.44033 & $\mathrm{~J}$ \\
Group 2. 24h & 6 & 0.42850 & $\mathrm{~K}$ \\
Group 3. Day 21 & 6 & 0.38450 & $\mathrm{~L}$ \\
Group 3. Day 10 & 6 & 0.33483 & $\mathrm{M}$ \\
Group 5. 24h & 6 & 0.32867 & $\mathrm{~N}$ \\
Group 4. 24h & 6 & 0.30833 & $\mathrm{O}$ \\
\hline
\end{tabular}

MTT: 3-(4,5-dimethylthiazol-2-yl)-2,5-diphenyltetrazolium bromide; SSEA-1: Stage-specific embryonic antigen-1; * Difference of means. ${ }^{* *}$ Groups that do not share a letter are significantly different. 




Figure 5. Bar graph of enzyme-linked immunosorbent assay analysis: Stage-specific embryonic antigen-1 expression of all groups. OD: Optical density.

differences arose and to prevent false positive results. So, the differences between the averages of the same sample groups were evaluated.

\section{RESULTS}

The viability of the chondrocytes in all groups was evaluated after 10 and 21 days of culture. Chondrocytes proliferated well in experimental groups, including the control in a time-dependent manner (Figure 4). P-PRP and P-PRP-containing hydrogels enhanced cellular viability particularly after 10 and 21 days of culture (Figure 4). Besides, P-PRP influenced the maturation of chondrocytes, increased the mitotic and adhesion activity and enhanced the formation of larger elliptical cells (Figure 3).
The difference between groups identified with variance analysis and Tukey HSD test was statistically significant (Tables II and III). Tukey pairwise comparisons showed a statistically significant difference between subgroups except for $10^{\text {th }}$ day of group 5 and $24^{\text {th }}$ hour of group 3, which were similar (Table III).

Compared to the control group, minimum SSEA-1 expression was detected at 24 hours in group 4 and group 5. Minimum SSEA-1 expression was detected in groups 3 and 5 on the $10^{\text {th }}$ day. However, on the $21^{\text {st }}$ day, minimum SSEA-1 expression was detected in group 3 compared to control group (Figure 5). Notably, maximum SSEA-1 expression was observed

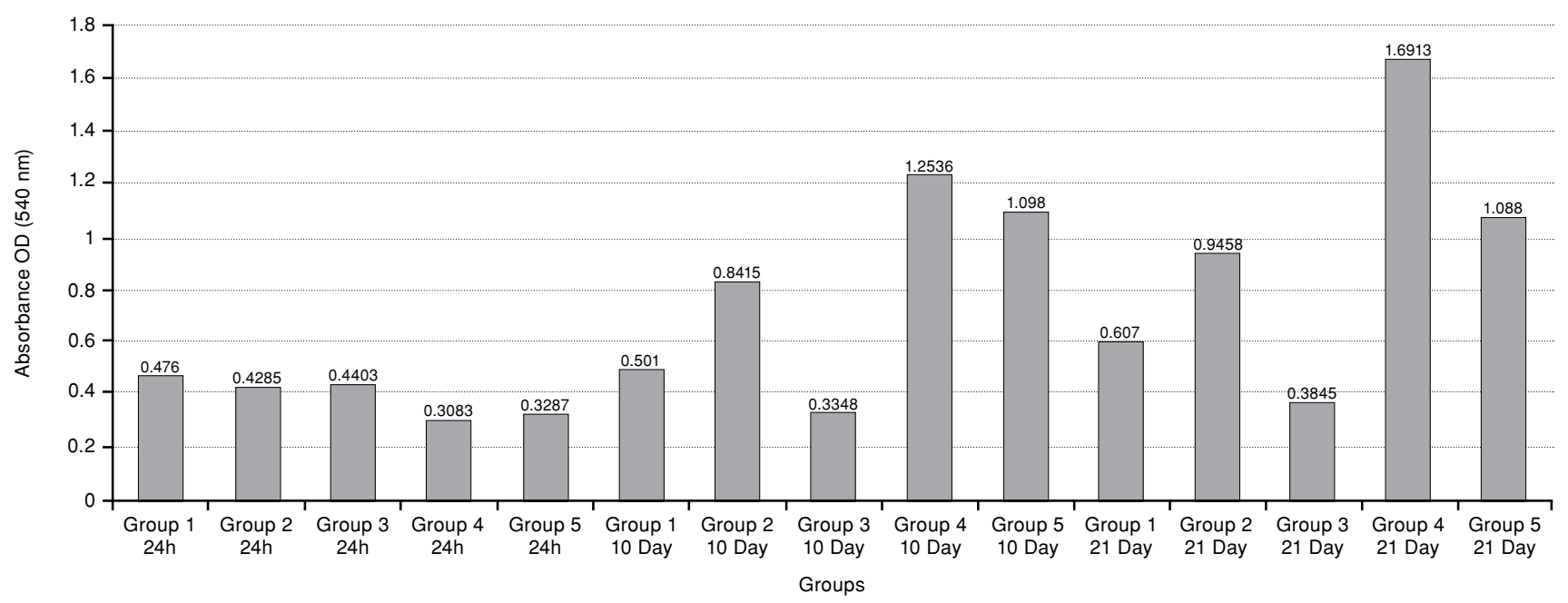

Figure 6. Bar graph of MTT analysis. OD: Optical density; MTT: 3-(4,5-dimethylthiazol-2-yl)-2,5-diphenyltetrazolium bromide. 
in group 4 on the $21^{\text {st }}$ day, followed by the $10^{\text {th }}$ day of group 4 .

MTT assay results were consistent with SSEA-1 ELISA results. Maximum viability was observed in group 4 on the $21^{\text {st }}$ day. Minimum viability was observed in groups 4 and 5 at 24 hours, followed by group 2 on the $10^{\text {th }}$ and $21^{\text {st }}$ days (Figure 6). SSEA-1 and MTT analyses showed statistically significant correlations $(\mathrm{p}=0.000$, Pearson product moment correlation coefficient $=0.745$ ).

\section{DISCUSSION}

Cartilage injuries resulting from osteoarthritis are clinical problems reducing the quality of life and which may cause severe disabilities. ${ }^{[13]}$ The self-repair capacity of cartilage is very limited. Besides, there is no admitted application or treatment protocol for present commercial drugs, and therefore different clinics use distinct treatment strategies. Consequently, the success rates of treatment are not high enough and usually patient satisfaction is not achieved. ${ }^{[14]}$ The consideration of all these reasons in the treatment of cartilage damage through replacement of tissue by biocompatible drug delivery systems represents the focus of recent research. ${ }^{[15]}$

Platelet-rich plasma as a storage vehicle of growth factors, such as platelet-derived growth factor, transforming growth factor- $\beta$, platelet-derived endothelial growth factor, vascular endothelial growth factor, and platelet factor 4, is used in therapy since $1990 s,{ }^{[16]}$ especially in wound healing. ${ }^{[17]}$ Many reports suggest that PRP activates the autocrine and paracrine system, inflammatory response, regulates chemotaxis, and induces the regulation of coagulation and cell differentiation. ${ }^{[18]}$

Therefore, PRP has been put into practice for treatment in almost all areas of medicine including sports medicine and orthopedics. ${ }^{[19]}$ Unfortunately, growth factors in PRP have a very short half-life. These growth factors are quickly metabolized by surrounding tissue and removed from the injection area. ${ }^{[6,20]}$ Because of this reason, high and repeated doses are used in intraarticular or systemic administration of PRP for an effective treatment. A great number of researches also reported that PRP diffuses micro-environment simply because of the difference in concentration and causes undesirable side effects. ${ }^{[21]}$

The goal of many researches is to improve delivery strategies or drug carrier systems for products like PRP in order to prevent degradation and maintain longer biological activity. ${ }^{[20]}$
A controlled drug delivery system is suitable to transport small amounts of growth factors, provide long-term release within a certain time period, eliminate the side and/or adverse effects caused by systemic administrations, as well as enhance the in vivo activity of growth factors. In this study, we have used a hydrogel prepared with non-toxic natural materials as a delivery system. As a result of our study, SSEA-1 expression was most abundant in the group treated with P-PRP applied with hydrogel (Day 21), besides cell viability and proliferation. This finding indicates that the hydrogel we have used maintained the stability and extended the half-life of growth factors in PRP.

We have also investigated the effect of the amount of leukocytes present in the PRP prepared by conventional methods. Many researches reported that leukocytes in the PRP interact with bone marrow-derived progenitor cells and support healing processes. ${ }^{[17,22]}$ Others ignore the effects of leukocytes or, in other words, the need for the removal of leukocytes in PRP. ${ }^{[23]}$ More importantly, to our knowledge, there are no clinical and/or preclinical studies revealing the amount of leukocyte and platelet content of PRP clearly.

In our study, proliferation, extracellular matrix formation and SSEA-1 expression were found to be lower in L-PRP-treated groups with a high leukocyte ratio than in groups treated with P-PRP. These results obtained with in vitro experiments need to be confirmed with animal studies. The influence of leukocytes on the biology of chondrocytes and their potential benefits should be carefully analyzed since this might shed light to many controversial data from the literature. ${ }^{[24]}$

A great number of researches published in the literature represent studies that were conducted on rats or rabbits as a model of mammalian. Although animal models are suitable to observe the systemic effects of PRP, animal tissue physiology and sensitivity differ from those of human tissue. ${ }^{[25-27]}$ Concerning the small amount of studies demonstrating the in vitro effects of different leukocyte concentrations of PRP, it was observed that these studies are on synoviocytes. ${ }^{[28]}$ or other tissues such as human ligament fibroblasts. ${ }^{[26]}$ To the best of our knowledge, in the literature, only one in vitro experimental study tested the effect of PRP on chondrocytes isolated from osteoarthritis tissue. Unfortunately, the cell cultures in this single study were established with tissues isolated only from four male patients. ${ }^{[4]}$ In our study, we used primary chondrocyte cultures obtained from both female 
and male patients who underwent surgery. There are many studies performed on cell lines; however, it is well documented that cell line physiology and even genetic differs from the original cell.

In this study, we have used primary chondrocyte cultures obtained from the chondral tissue comprised of cartilage cells and also the extracellular matrix components to investigate the effect of various PRP formulations on human chondrocytes in vitro. In vitro effects of two different formulations of PRP, P-PRP and L-PRP were tested by exposing chondrocytes with or without the presence of hydrogel. Cell proliferation, matrix production, and SSEA-1 expression were evaluated. All formulations that stimulated chondrocyte proliferation throughout the culture period were evaluated, and it was revealed that P-PRP applied with hydrogel induced greater cell growth and SSEA-1 expression compared with other formulations.

Stage-specific embryonic antigen-1, also known as CD15, is an antigenic epitope associated with cell adhesion, migration, and differentiation. It is expressed on differentiated adult human cartilage chondrocytes but not on dedifferentiated adult human cartilage chondrocytes. ${ }^{[29]}$

It is not sufficient to improve the proliferation of chondrocytes in a proper treatment. Ensuring the integrity of the tissue also requires the achievement of an intact extracellular matrix. Our results showed that the expression of SSEA-1 correlates with cell proliferation. Increased SSEA-1 expression was evaluated as maturated chondrocyte presence.

Limitations of our study is that we have have performed the experiments in vitro so the results cannot be generalized to the in vivo effects of PRP administration on cartilage tissue.

In conclusion, administration of P-PRP in the presence of a drug delivery system that supports controlled release not only increases cell proliferation but also supports extracellular matrix development. The identification of the optimal amounts and ratios of these blood components may ideally lead to a formulation more suitable for the treatment of cartilage lesions. Our findings have demonstrated that P-PRP should be used with a drug delivery system such as hydrogel. We believe that the results of our work may provide a significant contribution to the literature. However, it should be noted that our findings have been obtained from in vitro experiments. Further clinical research is needed to improve the effectiveness of PRP treatment in cartilage regeneration.

\section{Declaration of conflicting interests}

The authors declared no conflicts of interest with respect to the authorship and/or publication of this article.

\section{Funding}

This study was supported by grants (Project no: NKUBAP.00.10.AR.15.08) from Namik Kemal University Scientific Research Administration Division.

\section{REFERENCES}

1. Lu YC, Evans CH, Grodzinsky AJ. Effects of short-term glucocorticoid treatment on changes in cartilage matrix degradation and chondrocyte gene expression induced by mechanical injury and inflammatory cytokines. Arthritis Res Ther 2011;13:142.

2. Xie X, Zhang C, Tuan RS. Biology of platelet-rich plasma and its clinical application in cartilage repair. Arthritis Res Ther 2014;16:204.

3. Nurden AT, Nurden P, Sanchez M, Andia I, Anitua E. Platelets and wound healing. Front Biosci 2008;13:3532-48.

4. Atik OS. Is the evidence behind platelet-rich plasma therapies strong enough? Eklem Hastalik Cerrahisi 2012;23:1.

5. Cavallo C, Filardo G, Mariani E, Kon E, Marcacci M, Pereira Ruiz MT, et al. Comparison of platelet-rich plasma formulations for cartilage healing: an in vitro study. J Bone Joint Surg [Am] 2014;96:423-9.

6. Getgood A, Brooks R, Fortier L, Rushton N. Articular cartilage tissue engineering: today's research, tomorrow's practice? J Bone Joint Surg [Br] 2009;91:565-76.

7. Kellgren JH, Lawrence JS. Radiological assessment of osteo-arthrosis. Ann Rheum Dis 1957;16:494-502.

8. Perut F, Filardo G, Mariani E, Cenacchi A, Pratelli L, Devescovi V, et al. Preparation method and growth factor content of platelet concentrate influence the osteogenic differentiation of bone marrow stromal cells. Cytotherapy 2013;15:830-9.

9. Roffi A, Filardo G, Assirelli E, Cavallo C, Cenacchi A, Facchini A, et al. Does platelet-rich plasma freezethawing influence growth factor release and their effects on chondrocytes and synoviocytes? Biomed Res Int 2014;2014:692913.

10. Yilmaz I, Gokay NS, Gokce A, Tonbul M, Gokce C. A novel designed chitosan based hydrogel which is capable of consecutively controlled release of TGF-Beta 1 and BMP-7. Turkiye Klinikleri J Med Sci 2013;33:18-32.

11. Isyar M, Yilmaz I, Guler O, Mahirogullari M. Could platelet rich plasma be soaked to polymeric hydrogel which could be used at biological repair of cartilage? OTSHD 2015;4:40-51.

12. Available from: http://www.celprogen.com/details. php?pid=10765.

13. Atik OŞ, Erdoğan D, Seymen CM, Bozkurt HH, Kaplanoğlu GT. Is there crosstalk between subchondral bone, cartilage, and meniscus in the pathogenesis of osteoarthritis? Eklem Hastalik Cerrahisi 2016;27:62-7.

14. Das BR, Roy A, Khan FR. Cartilage oligomeric matrix protein in monitoring and prognostication of osteoarthritis and its utility in drug development. Perspect Clin Res 2015;6:4-9.

15. Mardones R, Jofré CM, Minguell JJ. Cell Therapy and Tissue Engineering Approaches for Cartilage Repair and/or 
Regeneration. Int J Stem Cells 2015;8:48-53.

16. Gehring S, Hoerauf $H$, Laqua $H$, Kirchner $H$, Klüter $H$. Preparation of autologous platelets for the ophthalmologic treatment of macular holes. Transfusion 1999;39:144-8.

17. Eppley BL, Pietrzak WS, Blanton M. Platelet-rich plasma: a review of biology and applications in plastic surgery. Plast Reconstr Surg 2006;118:147-59.

18. Marx RE. Platelet-rich plasma (PRP): what is PRP and what is not PRP? Implant Dent 2001;10:225-8.

19. Jo CH, Shin JS, Lee YG, Shin WH, Kim H, Lee SY, et al. Platelet-rich plasma for arthroscopic repair of large to massive rotator cuff tears: a randomized, single-blind, parallel-group trial. Am J Sports Med 2013;41:2240-8.

20. Mall NA, Tanaka MJ, Choi LS, Paletta GA Jr. Factors affecting rotator cuff healing. J Bone Joint Surg Am 2014;96:778-88.

21. Arora NS, Ramanayake T, Ren YF, Romanos GE. Platelet-rich plasma: a literature review. Implant Dent 2009;18:303-10.

22. "Wrotniak M, Bielecki T, Gaździk TS. Current opinion about using the platelet-rich gel in orthopaedics and trauma surgery. Ortop Traumatol Rehabil 2007;9:227-38.

23. Everts PA, van Zundert A, Schönberger JP, Devilee RJ, Knape JT. What do we use: platelet-rich plasma or plateletleukocyte gel? J Biomed Mater Res A 2008;85:1135-6.
24. Dohan Ehrenfest DM, Rasmusson L, Albrektsson T. Classification of platelet concentrates: from pure plateletrich plasma (P-PRP) to leucocyte- and platelet-rich fibrin (L-PRF). Trends Biotechnol 2009;27:158-67.

25. Dolkart O, Chechik O, Zarfati Y, Brosh T, Alhajajra F, Maman E. A single dose of platelet-rich plasma improves the organization and strength of a surgically repaired rotator cuff tendon in rats. Arch Orthop Trauma Surg 2014;134:1271-7.

26. Halpern BC, Chaudhury S, Rodeo SA. The role of plateletrich plasma in inducing musculoskeletal tissue healing. HSS J 2012;8:137-45.

27. Isyar M, Yilmaz I, Nusran G, Guler O, Yalcin S, Mahirogullari M. Safety of bioabsorbable implants in vitro. BMC Surg 2015;15:127.

28. Braun HJ, Kim HJ, Chu CR, Dragoo JL. The effect of plateletrich plasma formulations and blood products on human synoviocytes: implications for intra-articular injury and therapy. Am J Sports Med 2014;42:1204-10.

29. de la Fuente R, Abad JL, García-Castro J, FernándezMiguel G, Petriz J, Rubio D, et al. Dedifferentiated adult articular chondrocytes: a population of human multipotent primitive cells. Exp Cell Res 2004;297:313-28. 